УДК 633.854.54:631.559.2

DOI https://doi.org/10.32848/agrar.innov.2021.5.15

\title{
РОЛЬ МЕТЕОРОЛОГІЧНИХ ЧИННИКІВ У ФОРМУВАННІ ПРОДУКТИВНОСТІ ЛЬОНУ-ДОВГУНЦЮ В УМОВАХ ЛІСОСТЕПУ ЗАХІДНОГО ТА ПОЛІССЯ
}

\author{
ШУВАР А.М. - кандидат сільськогосподарських наук, старший науковий співробітник \\ http://orcid.org/0000-0002-6016-0896 \\ Інститут сільського господарства Карпатського регіону \\ Національної академії аграрних наук України \\ ШУВАР І.А. - доктор сільськогосподарських наук, професеор \\ http://orcid.org/0000-0002-4149-1761 \\ Львівський національний аграрний університет \\ РУДАВСьКА Н.М. - кандидат сільськогосподарських наук, старший науковий \\ співробітник \\ http://orcid.org/0000-0002-4443-5319 \\ Інститут сільського господарства Карпатського регіону \\ Національної академії аграрних наук України
}

Постановка проблеми. На сучасному етапі увага товаровиробників до традиційних та характерних для певних ґрунтово-кліматичних умов культур, які за умови відновлення потужностей переробляння забезпечують високу додану вартість якісної продукції, є добрими попередниками у сівозмінах різної ротації та формують стабільну урожайність. Такою культурою для умов Західного Лісостепу та Полісся є льон-довгунець, який у зазначених ґрунтово-кліматичних умовах може фрормувати значний високий біологічний і господарський урожай та є важливим джерелом виробництва волокна для текстильної промисловості, харчової рослинної олії, використання насіння в медичній галузі, виробництва технічних мастил, високобілкових кормів тощо.

Проте сьогодні недостатньо науково обґрунтовано процеси формування продуктивності льону-довгунцю за істотних змін кліматичних умов (температурного режиму та рівня зволоження за його вегетаційний період), а культура фрормує значно нижчу продуктивність за біологічно закладену.

Аналіз останніх досліджень і публікацій. Впродовж останніх двох десятирічь спостерігається підвищення температурного режиму, яке зумовлює кліматичні катаклізми як у світі загалом, так і в Україні зокрема. Ці явища зумовлюють різкі перепади тиску i, як наслідок, спричиняють значні коливання температур впродовж коротких часових періодів, зростання кількості стихійних лих. Багато авторів у своїх наукових працях звертають увагу на зниження продуктивності агроценозів озимих та ярих культур внаслідок змін клімату, інші вказують на адаптаційну здатність рослин та коректне вжиття агротехнологічних і селекційних заходів [1-5].

За розрахунками фахівців Гідрометцентру, кліматичні зони поступово мігрують на північ. Підвищення температури на $1^{\circ} \mathrm{C}$ пересуває межу агрокліматичних зон у середньому на 100 км [6].

Вітчизняні науковці [7] зазначають, що клімат України у тренді глобального потепління має тенденцію до випередження середньосвітової. Основним параметром зміни клімату є зміна середньої річної температури повітря нижнього шару атмосфери (на висоті 1 метр над поверхнею). Ії̈ визначають за даними вимірювань 163 метеорологічних станцій України, які мають безперервний період спостережень від 65 до 140 років. Тетяна Адаменко зазначає, що з 1991 року кожне наступне десятиріччя є теплішим за попереднє: 1991-2000 роки - на $0,5^{\circ} \mathrm{C}, 2001-2010$ роки на $1,2{ }^{\circ} \mathrm{C}, 2011-2019$ роки - на $1,7^{\circ} \mathrm{C}$.

Мета статі. Метою дослідження $€$ теоретичне обґрунтування та розроблення математичних моделей щодо доцільності розміщення посівів льону-довгунцю в ґрунтово-кліматичній зоні Полісся та Лісостепу Західного безпосередньо в регіоні з урахуванням його біокліматичного потенціалу.

Матеріали та методика досліджень. Для досягнення поставленої мети, аналізу статистичних даних та визначення їх вірогідності використовували дисперсійний, фракторіальний, кореляційний, регресійний методи.

Аналіз погодних умов і рівень їх мінливості за 2000-2020 роки порівняно із середніми багаторічними показниками проводився на основі критеріїв коефіцієнта суттєвості відхилень $\left(K_{C}\right)$ елементів агрометеорологічного режиму кожного з досліджуваних років від середніх багаторічних за такою формулою:

$$
K_{c}=\frac{\left(X_{i}-\bar{X}\right)}{S},
$$

де

$K_{C-}$ коефіцієнт суттєвості відхилень;

$X_{i}$ - елемент поточної погоди;

$X$ - показник середньої багаторічної величини;

$S$ - середнє квадратичне відхилення;

$i-$ порядковий номер року.

Результати досліджень. Зміна клімату відобразилася на вирощуванні більшості сільськогосподарських культур в Україні загалом та на виробництві льону-довгунцю зокрема. Виробництвом волокна з нього займалися спеціалізовані господарства, які вирощували цю культуру для потреб льонокомбінатів. Найкращими ґрунтово-кліматичними умовами для вирощування культури є зона Полісся, для якої характерні легкі за структурним складом ґрунти, та частина Лісостепової зони, здебільшого перехідної на сірих лісових ґрунтах. 
3 огляду на економічні чинники отримання готової продукції, високі затрати коштів на вирощування і переробку, а також відсутність зовнішніх ринків збуту готової продукції відбулися зміни посівних площ та обсягів виробництва волокна льону-довгунцю, що спричинило занепад галузі.

Аналіз статистичних даних FAOstat [8] відображає динаміку зміни посівних площ під льоном-довгунцем та рівень виробництва волокна за останні два десятиріччя. 32004 року відзначено стрімке скорочення площ посіву культури та рівня виробництва (рис. 1).

З 2009 року по 2018 рік посівні площі льону-довгунцю в Україні мали 1,0-1,8 тис. га та забезпечували виробництво волокна на рівні від 0,4 тис. т (2010 рік) до 1,34 тис. т у 2016 році. У розрізі ґрунтово-кліматичних зон України прослідковувалася аналогічна загальноукраїнській зміна посівних площ та рівня урожайності. У зоні Полісся культура займала площу до 32,2 тис. га (2004 рік), а за 10 років скоротила посівні площі до 1,0 тис. га. Динаміка скорочення посівних площ була доволі стрімкою та істотною (рис. 2).

32000 року (19,8 тис. га) до 2004 року посівні площі мали тенденцію до підвищення, забезпечуючи нарощування у середньому 1,2 тис. га щороку. 32004 року відзначено стрімке зниження до 10,3 тис. га у 2006 році, а також із 11,5 тис. га (2007 рік) до 1,0 тис. га у 2010 році.

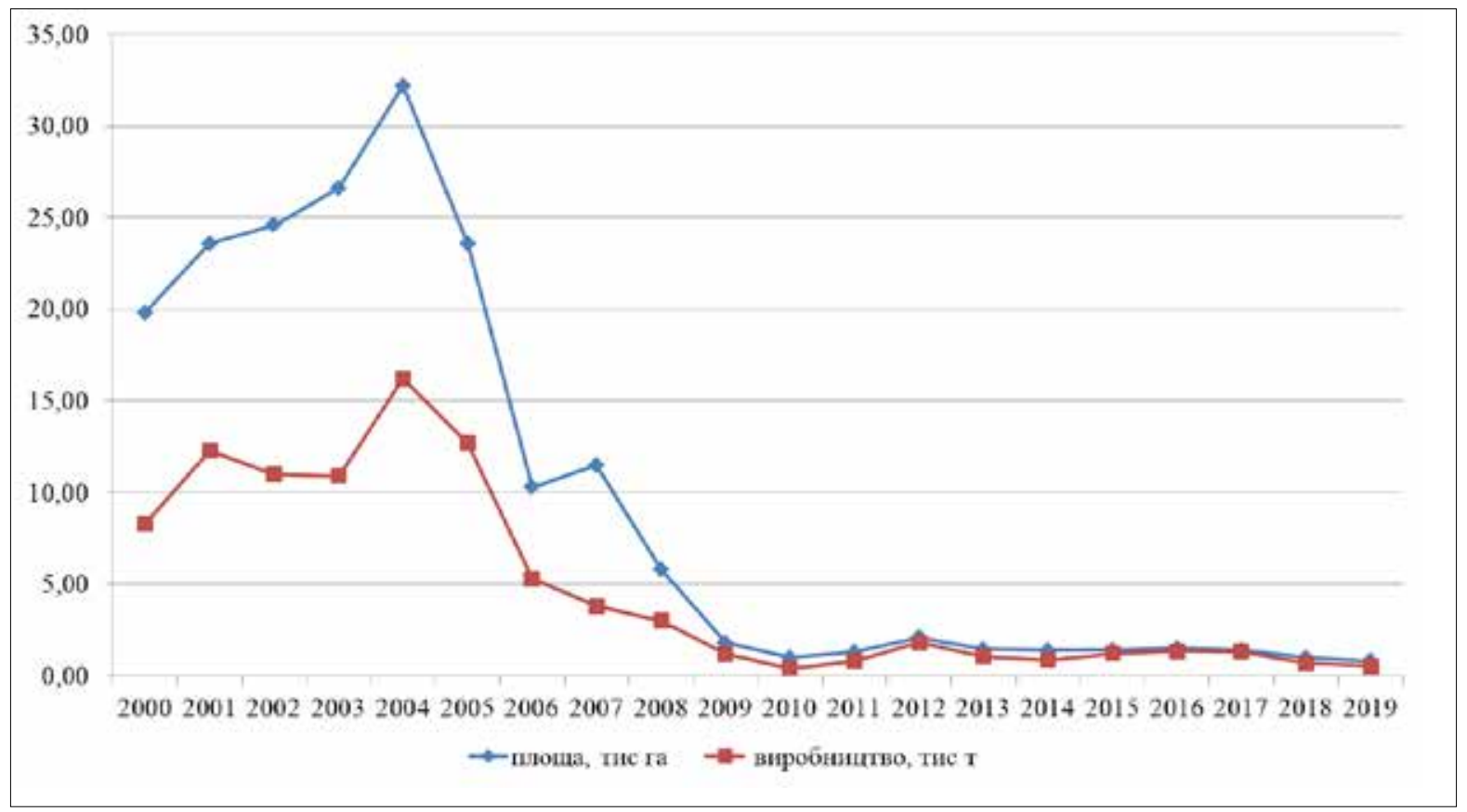

Рис. 1. Посівні площі та виробництво волокна льону-довгунцю в Україні, 2000-2019 роки (за даними FAOstat)

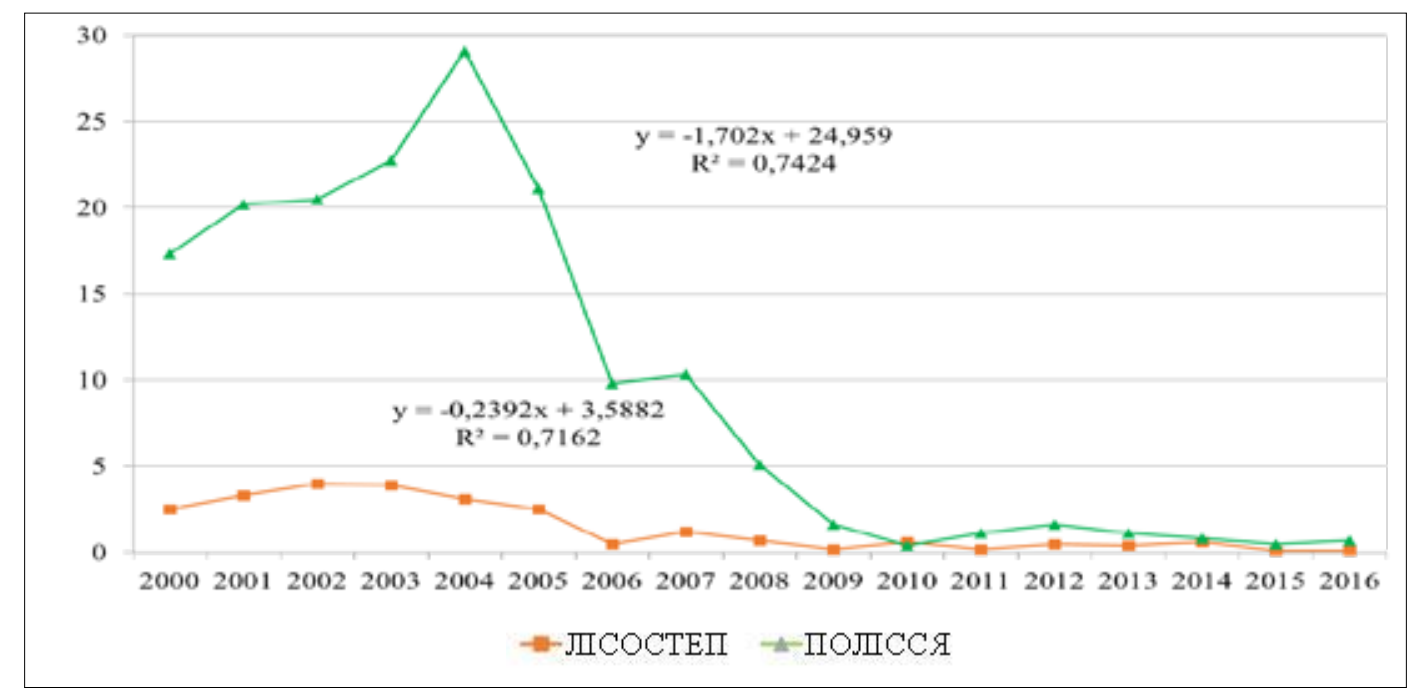

Рис. 2. Динаміка посівних площ льону-довгунцю, 2000-2016 роки (за даними Держкомстату України) 
32010 року коливання посівних площ під льоном-довгунцем було неістотним і складало від 2,10 тис. га (2012 рік) до 0,80 тис. га (2019 рік).

Зниження площ посіву льону-довгунцю у зоні Полісся

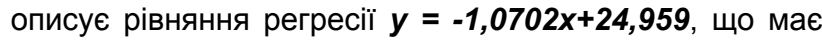
високий від'ємний кореляційний зв'язок $\boldsymbol{R}^{2}=\mathbf{0 . 7 4 2 4}$ Це свідчить про те, що у середньому за 20 років площі посіву культури скоротилися більш як на $55 \%$.

Щодо формування рівня урожайності волокна льону-довгунцю, то у середньому для зони Полісся він стабільно варіював (D=13,6\%) в межах 0,25 т/га у посушливому 2010 році до 0,81 т/га у 2012 році та описувався кореляційною лінійною залежністю $y=0,019 x+0,3681$ У розрізі областей зони Полісся найвищий рівень урожайності волокна льону-довгунцю забезпечувала Чернігівська область, де залежно від умов року урожайність складала 2,3-15,6 т/га. Останніми роками (2009-2016 роки) урожайність волокна $€$ незначною та варіюється на рівні 0,3-0,9 т/га. Високі показники продуктивності відзначено також у Житомирській (0,9-8,8 т/га), Львівській $(0,2-3,0$ т/га) та ІваноФранківській областях (0,1-1,9 т/га).

3 огляду на те, що у середньому незначні площі розміщення посівів льону-довгунцю, які $є$ відносно стабільними в зоні Лісостепу, в певні роки досягали 4 тис. га (2003 рік), посівні площі під цією культурою істотно зменшилися, а саме майже в 40 разів (до 100 га). Наше твердження обґрунтовується проведеними математичними розрахунками, а саме від'ємним кореляційним зв'язком,

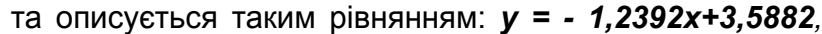
$R^{2}=0,7162$.

Основним виробником волокна льону-довгунцю впродовж усього терміну дослідження в цій зоні залишається Сумська область, займаючи площі під культурою від 0,2 тис. га (2009 рік) до 2,7 тис. га у 2003 році. За період із 2000 року вирощуванням льону-довгунцю займалися в Київській області (до 2005 рік) на площі 0,1-1,0 тис. га, Тернопільській області (2002-2007 роки) на площі 0,1-0,3 тис. га, та Чернівецькій області (до 2008 року) на площі 0,1-0,5 тис. га.

На незначних (до 100 га) площах та в окремі роки вирощували льон-довгунець у Хмельницькій, Черкаській та Вінницькій областях.

Аналіз статистичних даних за 2000-2016 роки свідчить про те, що стабільність формування урожайності льону-довгунцю в зоні Лісостепу практично відсутня $\left(R^{2}=0,1594\right)$ та нестабільна за рахунок як розривів розміщення у часі, так і врожайності окремих регіонів зони. 3 наведених даних чітко видно, що урожайність волокна досить істотно варіювалась від 0,36 т (2003 рік), 0,42 т (2007 рік) до 1,40 т (2006 рік) і 1,25 т (2013 рік).

За формуванням рівня урожайності найвищі показники забезпечувала Сумська область. Залежно від років урожайність волокна варіювалась від 0,32 до 1,32 т/га. Стосовно інших областей, то слід зазначить, що у Київській області кількість зібраного волокна складала 0,27-0,78 т/га (за період вирощування в регіоні у 2000-2006 роки), у Тернопільській області - 0,27-1,01 т/га (з 2001 по 2007 роки), у Чернівецькій області - 0,30-0,83 т/га (2000-2008 роки), у Хмельницькій області - 0,27-0,63 т/га (2000-2005 роки) і 0,53-0,69 т/га (2012-2016 рр.).

Спостереження та аналіз за метеорологічними явищами в Україні свідчать про регіональні зміни клімату. За даними Гідрометцентру відзначено підвищення середньорічної температури повітря, зміну тривалості та зростання теплозабезпечення вегетаційного періоду культур та істотне збільшення кількості й інтенсивності несприятливих метеорологічних явищ навіть у тих регіонах, для яких вони історично не є характерними.

Як зазначає Т.І. Адаменко, в Україні порівняно із середньомісячною нормою температура зимових місяців зросла до $2,5^{\circ} \mathrm{C}$. Поступово підвищується температура літньої вегетації. Відновлення весняних процесів останніми роками відбувається на 2-3 тижні раніше, а теплозабезпечення вегетаційного періоду збільшилось на $70-100^{\circ} \mathrm{C}$, а до 2030 року відбудеться зростання ресурсів тепла вегетаційного періоду ще на $300-500{ }^{\circ} \mathrm{C}[10]$.

Сталі врожаї сільськогосподарських культур забезпечують сприятливі кліматичні умови за безпосередньої потреби рослин у певну фразу росту й розвитку [11].

Аналіз кліматичних умов певного регіону дає можливість оптимізувати та диверсифікувати посівні площі сільськогосподарських культур, зокрема льону, сприяти реалізації закладеного біологічного потенціалу культури та вживати агротехнологічних заходів для підвищення рівня продуктивності.

Нами проаналізовано кліматичні чинники регіонів природно-кліматичної зони Полісся та Лісостепу Західного в межах Львівської області як репрезентативних щодо виробництва волокна льону.

Так, аналіз погодних умов за період вегетації льону-довгунцю в умовах Львівської області свідчить про нерівномірний тепловий режим та рівень зволоження у розрізі 2021 року (період 2000-2020 років). Зокрема, у квітні встановлено 11 випадків, які мали відхилення температурного режиму. 3 них 7 років квітень мав забезпеченість теплом нижчу, ніж за середньобагаторічне значення. Прохолодними роками були 2002-2004 роки, 2007 рік, 2015 рік, 2017 та 2020 роки, коли рівень температури варіювався в межах $7,2-8,7^{\circ} \mathrm{C}$ за середньобагаторічного значення $9,6^{\circ} \mathrm{C}$.

У трьох випадках (2000 рік, 2009 рік, 2016 рік) показники температурного режиму мали відхилення внаслідок підвищених температур повітря (10,4-12,0 $\left.{ }^{\circ} \mathrm{C}\right)$, а у 2018 році вони були наближені до екстремальних умов $\left(13,9^{\circ} \mathrm{C}\right)$.

Чіткої залежності та певної закономірності зволоження регіону від температурного режиму не було як за силою суттєвості відхилень, так і за частотою. Кожен рік характеризувався притаманним йому розподілом вологи за період, що аналізується. Так, у квітні відхилення в бік перезволоження мали 2000 рік, 2001 рік, 2005 рік, 2006 рік, 2012 рік, 2016 рік та 2019 рік за варіювання кількості опадів в межах 53-89 мм. Відхилення рівня зволоження внаслідок збільшення кількості опадів мали 2004 рік (21 мм), 2007 рік (26 мм), 2017 рік (35 мм), наближені до екстремальних умов 2018 та 2020 роки (24 та 18 мм відповідно) за середньобагаторічного показника кількості опадів на рівні 46 мм. 
Таблиця 1 - Коефіцієнти суттєвості відхилень середньомісячної температури повітря $\left({ }^{\circ} \mathrm{C}\right)$ і суми опадів (мм) у Львівській області за 2000-2020 роки

\begin{tabular}{|c|c|c|c|c|c|c|c|}
\hline \multirow{2}{*}{ Рік } & \multirow{2}{*}{$\begin{array}{c}\text { Кліматичні } \\
\text { фактори }\end{array}$} & \multicolumn{6}{|c|}{ Місяці року } \\
\hline & & III & IV & $\mathbf{V}$ & VI & VII & VIII \\
\hline \multirow{2}{*}{2000} & Температура & 0 & 1 & 1 & 0 & 2 & 0 \\
\hline & Опади & 1 & 1 & 1 & 1 & 2 & 2 \\
\hline \multirow{2}{*}{2001} & Температура & 0 & 0 & 0 & 1 & 1 & 0 \\
\hline & Опади & 2 & 1 & 1 & 2 & 1 & 0 \\
\hline \multirow{2}{*}{2002} & Температура & 2 & 1 & 2 & 0 & 2 & 0 \\
\hline & Опади & 2 & 0 & 1 & 2 & 2 & 0 \\
\hline \multirow{2}{*}{2003} & Температура & 1 & 1 & 2 & 0 & 0 & 0 \\
\hline & Опади & 2 & 0 & 0 & 1 & 0 & 2 \\
\hline \multirow{2}{*}{2004} & Температура & 0 & 1 & 1 & 1 & 1 & 1 \\
\hline & Опади & 0 & 1 & 0 & 2 & 0 & 2 \\
\hline \multirow{2}{*}{2005} & Температура & 2 & 0 & 1 & 1 & 0 & 1 \\
\hline & Опади & 0 & 1 & 0 & 1 & 1 & 1 \\
\hline \multirow{2}{*}{2006} & Температура & 2 & 0 & 1 & 1 & 1 & 1 \\
\hline & Опади & 1 & 1 & 2 & 1 & 0 & 2 \\
\hline \multirow{2}{*}{2007} & Температура & 2 & 1 & 1 & 1 & 1 & 0 \\
\hline & Опади & 0 & 1 & 1 & 0 & 1 & 1 \\
\hline \multirow{2}{*}{2008} & Температура & 2 & 0 & 1 & 0 & 1 & 0 \\
\hline & Опади & 1 & 1 & 0 & 2 & 2 & 0 \\
\hline \multirow{2}{*}{2009} & Температура & 1 & 1 & 1 & 1 & 0 & 1 \\
\hline & Опади & 1 & 0 & 0 & 2 & 2 & 0 \\
\hline \multirow{2}{*}{2010} & Температура & 0 & 0 & 0 & 0 & 1 & 1 \\
\hline & Опади & 2 & 0 & 2 & 2 & 1 & 1 \\
\hline \multirow{2}{*}{2011} & Температура & 1 & 0 & 0 & 0 & 1 & 0 \\
\hline & Опади & 2 & 0 & 2 & 0 & 2 & 0 \\
\hline \multirow{2}{*}{2012} & Температура & 1 & 0 & 1 & 0 & 2 & 0 \\
\hline & Опади & 2 & 1 & 1 & 2 & 1 & 1 \\
\hline \multirow{2}{*}{2013} & Температура & 2 & 0 & 1 & 1 & 1 & 0 \\
\hline & Опади & 2 & 0 & 2 & 2 & 2 & 2 \\
\hline \multirow{2}{*}{2014} & Температура & 2 & 0 & 0 & 1 & 1 & 1 \\
\hline & Опади & 0 & 0 & 1 & 1 & 1 & 2 \\
\hline \multirow{2}{*}{2015} & Температура & 1 & 1 & 1 & 0 & 0 & 2 \\
\hline & Опади & 0 & 0 & 2 & 2 & 2 & 2 \\
\hline \multirow{2}{*}{2016} & Температура & 1 & 1 & 0 & 1 & 0 & 1 \\
\hline & Опади & 2 & 1 & 2 & 1 & 1 & 2 \\
\hline \multirow{2}{*}{2017} & Температура & 2 & 1 & 0 & 1 & 1 & 1 \\
\hline & Опади & 0 & 1 & 0 & 2 & 1 & 2 \\
\hline \multirow{2}{*}{2018} & Температура & 2 & 2 & 1 & 1 & 0 & 1 \\
\hline & Опади & 0 & 2 & 1 & 2 & 2 & 0 \\
\hline \multirow{2}{*}{2019} & Температура & 2 & 0 & 1 & 2 & 1 & 0 \\
\hline & Опади & 2 & 1 & 2 & 2 & 2 & 1 \\
\hline חברת & Температура & 1 & 1 & 2 & 0 & 1 & 0 \\
\hline 2020 & Опади & 0 & 2 & 2 & 2 & 1 & 2 \\
\hline
\end{tabular}

Наближеним до екстремальних умов внаслідок підвищення температурного режиму травень був у 2002 році $\left(16,7^{\circ} \mathrm{C}\right), 2003$ році $\left(17,0^{\circ} \mathrm{C}\right), 2020$ році $\left(10,2^{\circ} \mathrm{C}\right)$ внаслідок недобору тепла за середньобагаторічного показника $14,3^{\circ} \mathrm{C}$. Умови травня 2001, 2010 , 2011, 2014, 2016 та 2017 років суттєво не різнилися за температурним режимом Решта років мала відхилення як за підвищення температурного режиму $(2000,2007$, 2012, 2013, 2018 роки), так і його зниження (2004-2006,
2008, 2009, 2015 та 2019 роки). Коливання температурного режиму у зазначених роках варіювалось у межах $15,1-17,0^{\circ} \mathrm{C}$ та $12,4-13,6^{\circ} \mathrm{C}$.

Надходження вологи у травні різнилося за 2000-2020 роки. Суттєвий дефіцит опадів відображений у 9 з 21 року (2000-2003, 2007, 2011-2013, 2016 та 2018 роки), серед них наближеними до екстремальних умов були 2011 рік (40 мм), 2013 рік (13 мм) та 2016 рік (50 мм) за середньобагаторічного показника 81 мм. Суттєве відхилення кількості опадів за надмірної зволоженості привело до того, що наближеними до екстремальних умов були 2006 рік (107 мм), 2010 рік (147 мм), 2015 рік (108 мм), 2019 та 2020 роки (158 та $161 \mathrm{мм);} \mathrm{у} 2014$ році (95 мм) суттєвість відхилення показника перебувала на рівні 1. За період літніх місяців не відзначено за температурних режимів років, які були наближені до екстремальних, окрім як по одному випадку у червні 2019 року $\left(21,3^{\circ} \mathrm{C}\right.$ за середньобагаторічної $17,8^{\circ} \mathrm{C}$ ), липні 2002 і 2012 років $\left(21,1\right.$ i $21,3^{\circ} \mathrm{C}$ за середньобагаторічної $\left.19,5^{\circ} \mathrm{C}\right)$ та серпні 2015 року $\left(21,5^{\circ} \mathrm{C}\right)$.

Коефіцієнти відхилення суми опадів за період літніх місяців мали високу строкатість за кількісними параметрами та суттєвістю відхилень. Так, рівні перезволоження червня 2001, 2002, 2009, 2010,2012, 2013, 2018 та 2020 років були наближеними до екстремальних умов за абсолютних значень кількості опадів (108-166 мм) за середньобагаторічного значення 89 мм.

Критично екстремальними за рівнем дефріциту вологи виявилися 2004 рік (47 мм), 2008 рік (55 мм), 2015 рік (47 мм), 2017 рік (45 мм) та 2019 рік (50 мм). Решта років, окрім 2007 та 2011 років (на рівні багаторічних значень), суттєво різнилися щодо незначного забезпечення вологою, кількість якої перебувала в межах 63-78 мм.

За розрахунками коефіцієнта суттєвості відхилень відображається забезпечення вологою липня за роками досліджень, а саме встановлено, що лише три роки з 21 були наближені до середньобагаторічних показників (2003, 2004 та 2006 роки мали 104-106 мм). Найбільша кількість випадків була викликана дефріцитом вологи (11 випадків), із них 5 наближені до екстремальних (2002, 2009, 2013, 2015 та 2019 роки) за кількості опадів 59-74 мм. Також наближеними до екстремальних умов, що зумовлено надмірним зволоженням, характеризувались 2000 рік (136 мм), 2001 рік (148 мм), 2008 рік (163 мм), 2011 рік (181 мм), 2018 рік (134 мм) порівняно із середньобагаторічним показником 104 мм.

Наближеними до екстремальних за рівнем дефіциту вологи у серпні були 2000, 2003, 2013, 2015-2017 та 2020 роки, коли кількість опадів варіювалась у межах 12-48 мм за середньобагаторічного показника 71 мм. Умови перезволоження 2004, 2006 та 2014 років наближали їх до екстремальних, значна кількість опадів (107-169 мм) в 1,5-2,4 рази переважала середньобагаторічний показник.

Аналізування кратності прояву несприятливих погодних умов, які одночасно були обумовлені високим температурним режимом та істотним дефріцитом кількості опадів, також свідчить лише про поодинокі випадки в окремі місяці окремих років, таких як квітень 2018 року, 
травень 2000, 2007, 2012, 2013, 2018 років, червень 2016, 2017 та 2019 років, липень 2007 та 2014 років, серпень 2015 та 2017 років, що мали складові частини посушливих явищ.

Загалом аналіз кратності прояву несприятливих погодних умов в регіонах зони Полісся за період 2000-2010 років, які викликані істотною зміною температурного режиму повітря, свідчить про те, що у середньому вони коливалися в межах від 37 (ІваноФранківська область) до 47 разів (Чернігівська область). Щодо суттєвості відхилень, то за період 2000-2010 років для регіонів цієї зони переважаючими були умови, які обумовлені низькими температурами за критерієм істотності відхилень. Найбільший дефіцит тепла за вегетацію лону мали Чернігівська область (28 випадків), Житомирська область (24 випадки), Рівненська область (22 випадки), Волинська область (21 випадок), Львівська область (20 випадків) та Івано-Франківська область (19 випадків) (табл. 2).

Щодо кількості випадків, які були обумовлені високими температурами, то найбільшу їх кількість мали Житомирська (20 випадків) та Львівська (21 випадок) області, а найменшу - Волинська (17 випадків), ІваноФранківська та Рівненська (по 18 випадків) області.

Загалом найвищою кратність прояву несприятливих погодних умов за величиною середньомісячної температури повітря характеризувалися Чернігівська (47 випадки) та Житомирська (44 випадки) області, найнижчою - Івано-Франківська та Волинська області (37 та 38 випадків).

Таблиця 2 - Кратність прояву несприятливих погодних умов впродовж вегетаційного періоду льону-довгунцю за величиною середньомісячної температури повітря та кількістю опадів (за 2000-2010 роки)

\begin{tabular}{|l|c|c|c|c|c|c|}
\hline \multirow{2}{*}{ Область } & \multicolumn{3}{|c|}{$\begin{array}{c}\text { Середньомісячна } \\
\text { температура пові- } \\
\text { тря, }\end{array}$} & \multicolumn{3}{|c|}{$\begin{array}{c}\text { Місячна сума опа- } \\
\text { дів, мм }\end{array}$} \\
\cline { 2 - 8 } & I $^{*}$ & II & III & I** & II & III \\
\hline Волинська & 21 & 17 & 38 & 26 & 28 & 54 \\
\hline Житомирська & 24 & 20 & 44 & 34 & 24 & 58 \\
\hline $\begin{array}{l}\text { Івано- } \\
\text { Франківська }\end{array}$ & 19 & 18 & 37 & 32 & 21 & 53 \\
\hline Львівська & $20 / 42$ & $21 / 38$ & $41 / 80$ & $21 / 50$ & $25 / 43$ & $46 / 93$ \\
\hline Рівненська & 22 & 18 & 40 & 22 & 19 & 41 \\
\hline Чернігівська & 28 & 19 & 47 & 26 & 18 & 44 \\
\hline
\end{tabular}

*। - умови обумовлені низькими температурами за критерієм істотності відхилень; II - обумовлені високими температурами; III - загальна кількість

** I - умови обумовлені недостатньою кількістю опадів за критерієм істотності відхилень; II - обумовлені надмірною кількістю опадів; III - загальна кількість

*** Львівська область - за період 2000-2010/20002020 років

Кратність прояву несприятливих погодних умов за величиною кількості опадів у розрізі досліджуваної природно-кліматичної зони варіювалась у межах 41-58 випадків. Найбільша їх кількість відзначена у Житомирській (58 випадки), Волинській (54 випадки) та Івано-Франківській (53 випадки) областях.

Так, за рівнем середньомісячної кількості опадів майже всі області мали по 21-34 випадки, які були обумовлені недостатньою кількістю опадів за критерієм істотності відхилень. Найменший прояв випадків мали західні області, а саме Львівська (21 випадок), Рівненська (22 випадки). Найбільшу кількість випадків за критерієм істотності відхилень мали Житомирська (34 випадки) та Івано-Франківська (32 випадки) області.

Слід відзначити, що у Житомирській, Львівській та Волинській областях за критерієм істотності відхилень, які обумовлені надмірною кількістю опадів, була зафріксована максимальна кількість випадків (від 24 до 28).

Щодо тривалого періоду (2000-2020 роки) виявлення несприятливих погодних умов за вегетаційний період у Львівській області, то слід відзначити, що за критерієм істотності відхилень, які викликані низьким температурним режимом, було в межах 42 випадків порівняно з умовами, які обумовлювали високий температурний режим, а саме 38 випадків. Однак за рівнем зволоження кількість випадків, які обумовлені десріцитом вологи, складала 53,8\%, 42,6\% випадків обумовлені надмірною кількістю опадів (93).

Останніми роками спостерігаються посухи в зонах Лісостепу Західного та на Поліссі, для яких традиційно утримувався більш-менш вологий клімат, які десятиліттями осушувалися для перетворення на ріллю, видобутку торфу тощо. Безсніжна зима 2019 року та безводна весна 2020 року виявили, що в зоні Полісся наявна нестача запасу води. Розораний ґрунт у вологих умовах легко промокає, а за посухи так само легко просихає і далі перетворюється на пил, тому ми спостерігали появу в регіоні пилових бур.

За результатами аналізу метеоумов для зон Лісостепу Західного та Полісся нами встановлено характер і тісноту зв'язку між метеорологічними умовами вегетаційного періоду та фрормуванням продуктивності льону-довгунцю.

Встановлено визначальні у формуванні врожаю умови місяці, тісноту їх зв'язку за величиною коефріцієнта кореляції (R) та частки участі фрактору (D).

Кореляційний аналіз дав змогу глибше дослідити взаємозв'язки між погодними умовами й виявити їх вплив на урожайність культури льону. Зокрема, кореляційна залежність між температурним режимом вегетаційного періоду та ссрормованого рівня врожаю в умовах Львівської області свідчить про помірну тісноту його зв'язку квітня-липня $(\mathrm{R}=0,328-0,476, \mathrm{D}=10,7-22,7 \%)$ та значну серпня $(R=0,556, D=30,9 \%)$, дольова участь якого складала $24,9 \%$ (табл. 3).

Між вологозабезпеченістю місяців вегетаційного періоду та продуктивністю культури помірний зв'язок мали квітень $(R=0,326, D=10,6 \%)$ та червень $(R=0,483$, $\mathrm{D}=23,3 \%)$. Решта місяців значно корелювала між показниками $R=0,501-0,629, D=25,1-39,6 \%$.

Визначальними у формуванні рівня урожайності волокна льону-довгунцю в умовах регіону за величиною множинного коефіцієнта кореляції $€$ травень $(R=0,640$, $D=41,0 \%)$ та липень $(R=0,702, D=49,3 \%)$. Сила зв'язку решти місяців була значною і характеризувалася такими показниками: $R=0,483-0,570, D=23,3-32,5 \%$. 
Таблиця 3 - Коефіцієнти парної та множинної кореляції між рівнем урожайності льону-довгунцю та метеоумов Львівської області (2000-2010 роки)

\begin{tabular}{|c|c|c|c|c|c|}
\hline \multirow{2}{*}{ Показник } & \multicolumn{7}{|c|}{ Місяці } \\
\cline { 2 - 6 } & $\mathbf{I V}$ & $\mathbf{V}$ & $\mathbf{V I}$ & VII & VIII \\
\hline \multicolumn{7}{|c|}{ Температура, ${ }^{\circ} \mathrm{C}$} \\
\hline R & 0,328 & 0,476 & 0,447 & 0,424 & 0,556 \\
\hline$\%$ & 14,7 & 21,3 & 20,1 & 19,0 & 24,9 \\
\hline D & 10,7 & 22,7 & 20,0 & 18,0 & 30,9 \\
\hline Кількість опадів, мм \\
\hline R & 0,422 & 0,629 & 0,483 & 0,502 & 0,501 \\
\hline$\%$ & 16,6 & 24,8 & 19,0 & 19,8 & 19,8 \\
\hline D & 17,8 & 39,6 & 23,3 & 25,2 & 25,1 \\
\hline \multicolumn{7}{|c|}{ Множинний коесріцієнт } \\
\hline R & 0,528 & 0,640 & 0,570 & 0,702 & 0,483 \\
\hline$\%$ & 18,1 & 21,9 & 19,5 & 24,0 & 16,5 \\
\hline D & 27,9 & 41,0 & 32,5 & 49,3 & 23,3 \\
\hline
\end{tabular}

Величина рівня реакції рослин льону-довгунцю на комплексну дію метереологічних чинників в умовах Волинської області, яка встановлена регресійним аналізом, свідчить про їх високий рівень тісноти $(R=0,542 \div 0,812, D=29,4 \div 65,9 \%)$. Найвищою дольовою участю характеризувалися квітень $(21,5 \%)$, травень $(23,0 \%)$ та липень (22,0\%).

Щодо комплексного впливу погодних умов (температурного режиму та рівня зволоженості) в умовах ІваноФранківської області, то регресійний аналіз свідчить про помірний (серпень) та середній рівень тісноти зв'язку з урожайністю культури $(R=0,374-0,679)$ за сили зв'язку $\mathrm{D}=14,0-46,1 \%$. Найбільший вплив сукупних факторів на фрормування урожайності забезпечували квітень (20,5\%), червень (22,5\%) та липень $(25,2 \%)$.

Величина рівня реакції рослин льону-довгунцю на комплексну дію метереологічних чинників в умовах Рівненської області, яка встановлена регресійним зв'язком, свідчить про їх високий рівень тісноти $(R=0,524 \div 0,733, D=27,5 \div 53,7 \%)$. Найвищою дольовою участю характеризувалися травень $(21,4 \%)$, червень $(21,6 \%)$ та липень $(22,2 \%)$.

Сукупність впливу комплексу погодних умов Чернігівської області через показник множинної кореляції свідчить про високий рівень тісноти зв'язку з урожайністю льону-довгунцю $(R=0,661 \div 0,773, D=43,7 \div 59,8 \%)$. Слід відзначити, що майже однаково впливають на формування рівня урожайності погодні умови як квітня, так і липня та серпня. Незначний вплив участі на формування урожаю $(12,6 \%)$ мав червень за помірної сили зв'язку $R=0,425$ та сили зв'язку $18,1 \%$.

За результатами регресійного аналізу впливу сукупності температурного режиму та розподілу опадів за вегетаційний період льону-довгунцю розроблено математичну регресійну модель формування рівня урожайності культури для зони Полісся (табл. 4). Ця модель свідчить про те, що у середньому для зони Полісся зв'язок має помірну силу $(R=0,392, D=15,4 \%)$. Це дає нам можливість дійти висновку, що погодні умови ґрунтово-кліматичної зони не мають істотного впливу на фрормування урожайності льону, тобто вони є пластичними стосовно рівня урожайності.
Таблиця 4 - Математична модель залежності урожайності льону-довгунцю від комплексу погодних умов зони Полісся за вегетацію (2000-2010 роки)

\begin{tabular}{|c|c|c|}
\hline $\begin{array}{c}\text { Математична } \\
\text { регресійна модель }\end{array}$ & $\begin{array}{c}\text { Множинний } \\
\text { коефіцієнт } \\
\text { кореляції (R) }\end{array}$ & $\begin{array}{c}\text { Коефіцієнт } \\
\text { детермінації } \\
(\mathrm{D}, \%)\end{array}$ \\
\hline $\begin{array}{c}Y^{*}=1,3058-0,3892 X_{1}+ \\
+0,0110 X_{1}^{2}-0,0069 X_{2}+ \\
+0,2553 X_{2}^{0,5}\end{array}$ & 0,392 & 15,4 \\
\hline
\end{tabular}

*Y - урожайність, т/га; $X_{1}$ - середня температура за вегетацію, ${ }^{\circ} \mathrm{C} ; \mathrm{X}_{2}-$ кількість опадів за вегетацію

Таким чином, розміщення цієї культури в ґрунтово-кліматичній зоні Полісся з тими параметрами погодних умов, які змінюються, є цілком виправданим і не має впливу на зниження рівня врожаю волокна.

Висновки. За критерієм основних показників погодних умов (температурнрий режим повітря, кількість опадів) їх відхилення від середньобагаторічних показників, інтенсивність, тривалість та кратність прояву несприятливих погодних умов, які були викликані високими або низькими температурами, рівнем зволоження, найсприятливішими для вирощування льону-довгунцю $є$ усі регіони випрощування.

За проведеним розрахунком множинного коефіцієнта кореляційної залежності комплексу погодних умов визначено, що високий рівень тісноти зв'язку з урожайністю волокна льону-довгунцю був визначальним для Волинської області (травень, $R=0,950, D=90,3 \%$, дольова участь місяця становила $25,0 \%$ ); Житомирської області (травень, $R=0,812, D=65,9 \%$, дольова участь місяця становила 23,0\%); Івано-Франківської області (липень, $R=0,679, D=46,1$, дольова участь місяця становила 25,2\%); Львівської області (липень, $\mathrm{R}=0,702$, $\mathrm{D}=49,3 \%$, дольова участь місяця становила $24,0 \%$ ); Рівненської області (липень, $\mathrm{R}=0,773, \mathrm{D}=53,7 \%$, дольова участь місяця становила $22,2 \%$ ); Чернігівської області (квітень, липень, серпень, $\mathrm{R}=0,749-0,773$, $D=56,1-59,8 \%$, дольова участь місяців становила 22,2, $22,8$ та $22,9 \%)$.

\section{СПИСОК ВИКОРИСТАНОЇ ЛІТЕРАТУРИ:}

1. Зубов О.Р., Зубова Л.Г., Славгородська Ю.В. Оцінка впливу метеорологічних факторів на врожайність озимих культур в умовах північної частини Луганської області. Вісник Полтавської державної аграрної академії. 2012. № 2. С. 14-20.

2. Камінський В.Ф., Голодна А.В., Гресь С.А. Значення погодно-кліматичних умов у виробництві зернобобових культур в Україні. Корми і кормовиробництво. 2004. Вип. 53. С. 38-48.

3. Лопатинська А.Ю. Очікувані наслідки зміни клімату. Вісник Дніпропетровського університету. 2011. Вип. 5(2). С. 26-33.

4. Стефрановська Т.Р., Підліснюк В.В. Оцінка вразливості змін клімату сільського господарства України. Екологічна безпека. 2010. № 1(9). С. 62-66.

5. Трипольська Г.М. Як проявляється зміна клімату в Україні? URL: https://ua.boell.org/uk/2020/06/09/ yak-proyavlyaetsya-zmina-klimatu-v-ukraini. 
6. В Україні агрокліматичні зони змістилися на 200 KM. URL: https://agravery.com/uk/posts/show/vukraini-agroklimaticni-zoni-zmistilisa-na-200-km.

7. Адаменко Т.І. Зміна клімату та сільське господарство в Україні: що варто знати фермерам? Німецькоукраїнський агрополітичний діалог. 2019. 34 с.

8. ЧеховаІ.В., ЧеховС.А.,ШкуркоМ.П.Вітчизнянийринок льону. Економіка України. 2017. № 1 (662). С. 52-63.

9. Висновок на проєкт Закону України «Про внесення змін до Закону України «Про ставки вивізного (експортного) мита на насіння деяких видів олійних культур» щодо скасування вивізного (експортного) мита на насіння льону, подрібненого або неподрібненого, та рижію» (реєстр. № 4737 від 31 травня 2016 року). URL: https://ips.ligazakon.net/document/XH3NL00A.

10. Заблоцька Т.М., Скриник О.А. Прогнозування дат стійкого переходу середньої добової температури повітря через зазначені межі. Наукові праці УкрНДГМІ. 2009. Вип. 258. С. 84-105.

11. Демолон А. Рост и развитие культурных растений. Москва, 1961. 400 с.

\section{REFERENCES:}

1. Zubov, O.R., Zubova, L.H. \& Slavhorodska, Yu.V. (2012). Otsinka vplyvu meteorolohichnykh faktoriv na vrozhainist ozymykh kultur v umovakh pivnichnoi chastyny Luhanskoi oblasti [Assessment of the influence of meteorological factors on the yield of winter crops in the northern part of Luhansk region]. Visnyk Poltavskoi derzhavnoi ahrarnoi akademii - Bulletin of the Poltava State Agrarian Academy, 2, 14-20 [in Ukrainian].

2. Kaminskyi, V.F., Holodna, A.V. \& Hres, S.A. (2004). Znachennia pohodno-klimatychnykh umov u vyrobnytstvi zernobobovykh kultur v Ukraini [Importance of weather and climatic conditions in the production of legumes in Ukraine]. Kormy i kormovyrobnytstvo Feed and feed production, 53, 38-48 [in Ukrainian].

3. Lopatynska, A.Yu. (2011). Ochikuvani naslidky zminy klimatu [Expected consequences of climate change]. Visnyk Dnipropetrovskoho universytetu - Bulletin of Dnipropetrovsk University, 5, 26-33 [in Ukrainian].

4. Stefanovska, T.R. \& Pidlisniuk, V.V. (2010). Otsinka vrazlyvosti zmin klimatu silskoho hospodarstva Ukrainy [Assessment of the vulnerability of climate change in agriculture in Ukraine]. Ekolohichna bezpeka Ecological safety, 1 (9), 62-66 [in Ukrainian].

5. Halyna Trypolska. Yak proyavlyayet'sya zmina klimatu $\checkmark$ Ukrayini? [How is climate change manifesting itself in Ukraine?] URL: https://ua.boell.org/uk/2020/06/09/yakproyavlyaetsya-zmina-klimatu-v-ukraini [in Ukrainian].

6. V Ukrainy ahroklimatychni zony zmistylysia na $200 \mathrm{~km}$ [In Ukraine, agro-climatic zones have shifted by $200 \mathrm{~km}$ ]. URL: https://agravery.com/uk/posts/show/v-ukrainiagroklimaticni-zoni-zmistilisa-na-200-km [in Ukrainian].

7. Tetiana, Adamenko. (2019). Zmina klimatu ta silske hospodarstvo v Ukraini: shcho varto znaty fermeram? [Climate change and agriculture in Ukraine: what should farmers know?]. Nimetsko-ukrainskyi ahropolitychnyi dialoh - German-Ukrainian agropolitical dialogue [in Ukrainian].

8. Chekhova, I.V., Chekhov, S.A. \& Shkurko, M.P. (2017) Vitchyznianyi rynok lonu [Domestic flax market]. Ekonomika Ukrainy - Economy of Ukraine, 1 (662), 52-63 [in Ukrainian].
9. Vysnovok na proekt Zakonu Ukrainy "Pro vnesennia zmin do Zakonu Ukrainy "Pro stavky vyviznoho (eksportnoho) myta na nasinnia deiakykh vydiv oliinykh kultur" shchodo skasuvannia vyviznoho (eksportnoho) myta na nasinnia lonu, podribnenoho abo nepodribnenoho, ta ryzhiiu" (reiestr. N 4737 vid 31.05.2016) [Opinion on the draft Law of Ukraine "On Amendments to the Law of Ukraine" On Rates of Export (Export) Duties on Seeds of Certain Types of Oilseeds "On Abolition of Export (Export) Duties on Flax Seeds, Crushed or Uncrushed, and Rice" (register. N 4737 of 31.05.2016)]. URL: https://ips.ligazakon.net/document/XH3NL00A [in Ukrainian].

10. Zablotska, T.M. \& Skrynyk, O.A. (2009). Prohnozuvannia dat stiikoho perekhodu serednoidobovoi temperatury povitria cherez zaznacheni mezhi [Forecasting the dates of a stable transition of the average daily air temperature across these limits]. Naukovi pratsi UkrNDHMI - Scientific works of UkrNDGMI, 258, 84-105 [in Ukrainian].

11. Demolon, A. (1961). Rost y razvytye kulturnykh rastenyi [Growth and development of cultivated plants]. Moscow [in Russian].

Шувар А.М., Шувар І.А., Рудавська Н.М. Роль метеорологічних чинників у формуванні продуктивності льону-довгунцю в умовах Лісостепу Західного та Полісся

Мета. Метою статті $€$ теоретичне обґрунтування та розроблення математичної моделі щодо доцільності розміщення посівів льону-довгунцю в ґрунтово-кліматичній зоні Полісся та Лісостепу Західного безпосередньо в регіоні з урахуванням його біокліматичного потенціалу. Методи. Для аналізу статистичних даних та визначення їх вірогідності використовували дисперсійний, фракторіальний, кореляційний, регресійний методи. Аналіз погодних умов і рівень їх мінливості за період 20002020 року порівняно із середніми багаторічними показниками проводився на основі критеріїв коефіцієнта суттєвості відхилень $\left(K_{c}\right)$ елементів агрометеорологічного режиму кожного з досліджуваних років від середніх багаторічних. Результати. Аналіз статистичних даних за 2000-2016 роки свідчить про те, що стабільність формування урожайності льону-довгунцю в зоні Лісостепу практично відсутня $\left(R^{2}=0,1594\right)$ та нестабільна за рахунок як розривів розміщення у часі, так і врожайності окремих регіонів зони. Урожайність волокна істотно варіювалась від 0,36 т (2003 рік), 0,42 т (2007 рік), до 1,40 т (2006 рік) і 1,25т (2013 рік). Спостереження та аналіз за метеорологічними явищами в Україні свідчать про регіональні зміни клімату. Відзначено підвищення середньорічної температури повітря, зміну тривалості та зростання теплозабезпечення вегетаційного періоду льону, а також істотне збільшення кількості та інтенсивності несприятливих метеорологічних явищ навіть у регіонах. Кратність прояву несприятливих погодних умов за величиною кількості опадів варіювалась у межах 41-58 випадків. Найбільша їх кількість відзначена у Житомирській (58 випадки), Волинській (54 випадки) та Івано-Франківській (53 випадки) областях. Встановлено, що між вологозабезпеченістю місяців вегетаційного періоду та продуктивністю льону-довгунцю в умовах зон Львівської області помірний зв'язок мали квітень $(R=0,326, D=10,6 \%)$ та червень $(R=0,483$, $\mathrm{D}=23,3 \%)$. Решта місяців значно корелювала між показ- 
никами $R=0,501-0,629, D=25,1-39,6 \%$. За результатами регресійного аналізу впливу сукупності температурного режиму та розподілу опадів за вегетаційний період льону-довгунцю розроблена математична регресійна модель формування рівня урожайності культури для зони Полісся, яка свідчить про те, що у середньому для зони зв'язок має помірну силу $(R=0,392, D=15,4 \%)$. Висновки. Погодні умови ґрунтово-кліматичної зони не мають істотного впливу на формування урожайності льону, тобто $є$ пластичними стосовно рівня урожайності. За розрахунком множинного коефіцієнта кореляційної залежності комплексу погодних умов визначено, що високий рівень тісноти зв'язку з урожайністю волокна льону-довгунцю був визначальним для Волинської області (травень, $\mathrm{R}=0,950, \mathrm{D}=90,3 \%$ ); Житомирської області (травень, $R=0,812, \mathrm{D}=65,9 \%$ ); Івано-Франківської області (липень, $R=0,679, D=46,1$ ); Львівської област (липень, $\mathrm{R}=0,702, \mathrm{D}=49,3 \%$ ): Рівненської област (липень, $\mathrm{R}=0,773, \mathrm{D}=53,7 \%$ ); Чернігівської області (квітень, липень, серпень, $\mathrm{R}=0,749-0,773, \mathrm{D}=56,1-59,8 \%)$.

Ключові слова: льон-довгунець, режим зволоження, температурний режим, продуктивність волокна.

Shuvar A.M., Shuvar I.A., Rudavska N.M. The role of meteorological factors in the formation of long flax productivity in the Forest-Steppe of Western and Polissya

Purpose. Theoretically substantiate and develop mathematical models for the feasibility of locating fiber flax in the soil-climatic zone of Polissya and the Western Forest-Steppe zone of the directly in the region, including its bioclimatic potential. Methods. Dispersion, factorial, correlation, and regression methods were used to analyze statistical data and determine their probability. The analysis of weather conditions and the level of their variability for the period 2000-2020 in comparison with average longterm indicators were carried out on the basis of criteria of coefficient of materiality of deviations (Ks) of elements of an agrometeorological mode of each of investigated years from average long-term. Results. The analysis of statistical data for 2000-2016 shows that the stability of the formation of fiber flax yield in the Forest-Steppe zone is almost absent $\left(R^{2}=0.1594\right)$ and unstable, both due to time gaps and yields of individual regions of the zone. Fiber yields varied significantly from 0.36 tons (2003), 0.42 tons (2007), to 1.40 tons (2006) and 1.25 tons (2013). Observations and analysis of meteorological phenomena in Ukraine indicate regional climate change. An increase in the average annual air temperature, a change in the duration and increase in heat supply of the flax growing season and a significant increase in the number and intensity of adverse meteorological phenomena, even in the regions. The frequency of adverse weather conditions in the amount of precipitation varied between 41-58 cases. The largest number of them was observed in Zhytomyr (58 cases), Volyn (54 cases) and Ivano-Frankivsk (53 cases) regions. It was established that April $(R=0.326, D=10.6 \%)$ and June $(R=0.483, D=23.3 \%)$ had a moderate relationship between the moisture supply of the growing season months and the productivity of long flax in the zones of Lviv region. The remaining months were significantly correlated between $R=0.501-0.629, D=25.1-39.6 \%$. Based on the results of regression analysis of the influence of the set of temperature regime and precipitation distribution during the growing season of flax, a mathematical regression model of crop yield formation for Polissya zone was developed, which shows that on average for the zone the connection has moderate strength $15.4 \%$. Conclusions. Weather conditions of the soil-climatic zone do not have a significant impact on the formation of flax yield, i.e. are plastic in relation to the yield level. According to the calculation of the multiple correlation coefficient of the complex of weather conditions, it was determined that the high level of closeness of the connection with the yield of long flax fiber was decisive for: Volyn reg. - May $(R=0.950$, $\mathrm{D}=90.3 \%)$; Zhytomyr reg. - May $(\mathrm{R}=0.812, \mathrm{D}=65.9 \%)$; Ivano-Frankivsk reg. - July $(R=0.679, D=46.1)$; Lviv reg. - July $(R=0.702, D=49.3 \%)$ : Rivne reg. - July $(R=0.773, D=53.7 \%)$; Chernihiv reg. - April, July, August $(R=0.749-0.773, D=56.1-59.8 \%)$.

Key words: fiber flax, humidification mode, temperature regime, fiber productivity. 